\title{
Tyranny of Corporate Dominance Exemplified by Food Supply in Modern-Day Britain
}

\author{
Alan Hallsworth \\ University of Portsmouth, United Kingdom \\ Alfred Wong \\ Friends of Aboriginal Health, Canada
}

\begin{abstract}
Food supply incorporates both production and distribution. During the past few decades, large corporations have steadily gained control over food supply. This increased dominance is a result of, among other things, the continuation of neoliberal free-market government policies. Because of the legal mandate of modern corporations, the psychopathic pursuit of profit for their shareholders is a natural undertaking. In particular, four multiples now control a significant segment of the grocery market in Britain. Because of such pervasive presence, the major multiples are shaping the preference and choices of the grocery buying public. Such corporate dominance is a form of tyranny whenever it limits the free will and choices of the population at large. Despite periodic vocal public indignation and outcries against such "abuses", many middle income citizens continue to drive cars to large supermarkets to do virtually all their grocery shopping conveniently under "one roof". The scope of action available to the public to redress this imbalance is greatly circumscribed.
\end{abstract}

\section{Keywords}

Agriculture, corporation, food supply, social justice, trade

\section{Introduction}

Recent decades have witnessed increasing public outcries in Britain about the ever increasing dominance of large supermarket ${ }^{1}$ multiples in the grocery sector. Destruction of traditional urban landscapes and neighbourhood grocery stores, are among the many alleged misdeeds committed by these large food retailers. There are many appeals for ethical practices of honesty, fairness, etc. as public entitlements. Before any redress of these contentious practices could be undertaken, certain perplexing questions would need to be answered: where do ethical obligations, if any, originate? are behaviours of these large supermarket multiples totally abnormal?

Is business ethics an oxymoron? The foundation of western European, (for present purposes, British), civilization is rooted in Christianity; so how were Christian ethics themselves formed and shaped?

Copyright (C) 2015 Victoria University. This document has been published as part of the Journal of Law and Governance in both online and print formats. Educational and non-profit institutions are granted a non-exclusive licence to utilise this document in whole or in part for personal or classroom use without fee, provided that correct attribution and citation are made and this copyright statement is reproduced. Any other usage is prohibited without the express permission of the publisher. Prior to the advent of Christianity, ethics had evolved for millennia and been codified generally in ecclesiastical media as a means to maintain social peace and order (Freeman 2009: Chapter 2). In the earliest form, Christian ethics had essentially evolved from the older Judaic practices in the Levant, in which cooperative common weal was the foundation. The form of Christianity eventually introduced to Britain was the

\footnotetext{
${ }^{1}$ Supermarkets are typically multiple food retailers which are owned wholly by a large corporation. In this paper, 'corporation' denotes a business entity, privately held or publicly traded, which has substantial annual revenue.
} 
results of many revisions, modifications and wilful interpretative translations from Aramaic and/or Hebrew to Greek and subsequently to Latin. Thus, (Christian) ethics do not appear to have a primeval origin in natural laws. Friedrich Nietzsche (1844-1900) wrote succinctly that ethics and morality are relative in time and space, as they are shaped by, among other things, prevailing cultural and social conditions. In essence, what are acceptable ethical norms today may have been roundly condemned in past years vice versa. Ethics are often added or subtracted by fiat for economic and/or political expediency.

The principles of Christian ethics evolved further in Britain largely along the "Estates" social structure throughout the following centuries until the dawn of the Age of Enlightenment (syn. Age of Reason) in the 17th and 18th centuries, when reason and individualism were heralded over tradition. Early public discourse over the (in)compatibility of the "New Age" with prevailing Christian practices could be found in the works of such notable British philosophers as Thomas Hobbes (1588-1679), John Locke (1632-1704) and David Hume (1711-1776). The virtues of liberal free-market capitalism were first described at length by Adam Smith (1723-1790) during the era of the Industrial Revolution in Britain. The peculiar British utilitarian concept of ethics and morality was entrenched further by the works of Jeremy Bentham (1748-1832) and John Stuart Mill (1806-1873).

Nevertheless, the "good" ethics of charity, obedience, piety, generosity, honesty, fairness, etc., reflecting, to a large extent, the teachings in the very early days of Christianity (Calvalier et al. 1990) have since become canonized - albeit continually modified and often diluted - at least in the formal teachings of the Christian churches in Britain. An example is the rapid decline of obedience from ecclesiastical teachings in the aftermath of the short-lived 1381 English peasants' revolt (Bisson, 1998: Chapter 7). In modern times, interpretation and personal practices of Christian ethics remain highly influenced by British utilitarianism of the 17th and 18th Centuries. Rationality is sought largely through the insidious glorification of personal wealth, over all other humanistic concerns. It is always presumed that successive instant gratifications must cumulate into real long-term benefits.

The definition of (Christian) ethics remains elusive and variable, especially in the context of modern business practices. It follows that popularized "ethical investment" is also somewhat disingenuous as it is predicated on how "ethics" is defined, albeit temporaly. In reality, "ethical investment" is often cloaked largely in the context of self-interest in gaining greater financial returns. Other negative external consequences are often selectively ignored. For example, if one invests in the establishment of a vacation hotel for foreign tourists in St. Lucia (Caribbean) ostensibly to facilitate the creation of gainful employment for the local people, this "ethical investment" could just as easily be portrayed as the extension of neo-colonial enslavement of the people of St. Lucia (Wong, 2015). Ultimately, cui bono?

According to the Concise Oxford Dictionary (9th Edition), tyranny is defined to be the cruel and arbitrary use of authority, and cruelty embodies the indifference to another's suffering. It is obvious that dominance over food supply could not be considered to be inherently cruel or oppressive. However, tyranny as described by John Locke (1632-1704) might be more pertinent. Although Locke has also been depicted as a proto-liberal capitalist to justify the English ruling

class of the day, he wrote aptly in his Two Treatises of Government that "...... tyranny is the exercise of power beyond right, which nobody can have a right to; and this is making use of the power any one has in his hands, not for the good of those who are under it, but for his own private, separate advantage." (Locke 1689: Chapter XVIII, Sec. 199). Thomas Hobbes, too, wrote in this vein: seeing only the Monarch as living in an unfettered state of nature. The abuse of market power by corporations through pricing and other control instruments that ensure self-enrichment could thus be considered rightly to be a form of tyranny, since food is an essential of life. Witness the classical example of British Government's indifference to the suffering of the Irish during the Irish potato famine in the mid-1800s (see, for example, Woodham-Smith, 1962; Delaney 2012). Food was readily available for purchase; but the poorest Irish without paid employment had no money to buy the essentials of life. The free market ideology thus determined who lived or died. As Elster (2007: 174) 
had noted, "when the Irish fled the famine in the 1840s (it was) the poorest (who) stayed home to die". The attendant depopulation of Éire may also have purposefully served the interests of the AngloIrish aristocracy by allowing them to consolidate and expand their hegemony in Éire (see, for example, Kinealy 1997; Ó Murchadha 2011; Coogan 2012; Kelly 2012).

Since the Industrial Revolution, corporations have progressively supplanted governments as "tyrants", usually with the connivance of governments themselves. An analogy that stresses this corporationtyranny link is offered by the familiar 1946 mining song 'Sixteen Tons' by Tennessee Ernie Ford http://www.cowboylyrics.com/lyrics/classic-country/sixteen-tons---tennessee-ernie-ford-14930.html).

\author{
"You load sixteen tons, what do you get \\ Another day older and deeper in debt \\ Saint Peter don't you call me 'cause I can't go \\ I owe my soul to the company store"
}

A current example involves companies conducting resource extraction activities (e.g., mining and logging) in remote regions of developed countries such as Australia and Canada, or in developing countries such as Indonesia and Peru, which routinely demand that their workers must purchase all foods from the company store at whatever exploitive prices set by the company. Predictably there are no other food supplies at these remote sites where access is controlled by the company.

Here we examine the tyranny of corporate dominance, as exemplified by the food sector, on modernday society in Britain, with particular reference to supermarkets. The principal issues to be discussed are the role, if any, of ethics of corporate practices, psychopathology of profit seeking, and the evolution of corporate power during the last quarter of the 20th Century.

\title{
Food supply in contemporary Britain
}

Food supply incorporates both production and distribution. The local production of foods has diminished greatly during the past few decades with improvements in transportation logistics (Hallsworth and Wong 2012) and substantial rises in the cost of local farm labour (Wong and Navarro 2014). For example, fresh vegetables can now be grown efficiently in Spain and shipped economically by lorries to the British market (Hallsworth and Wong 2012). The other critical element of distribution affecting food supply is shaped to a large extent by the rapid rise of mega food businesses, which invariably dictate production, including location, quantity and farm-gate pricing.

It is generally recognized that the power of large agri-food production businesses such as Premier Foods Group Ltd. and Unilever PLC is enormous and that this sector is not without its critics (see for example Lymbery and Oakeshott 2014). It is however questionable if their power surpasses that of food retailers since the latter unilaterally control access to the shelf space of stores in which fresh or processed foods are displayed and sold to the public at large.

Food supply in Britain evolved in line with, and to an extent limited, the expansion of great cities. Before the advent of modern refrigeration/preservation technologies, key produce such as milk had, of necessity, to be supplied from farms locally - even in London where butter came from Epping. Such trends have been chronicled by Atkins (2003). One result was that now-urbanised parts of London were associated with agriculture (artichokes came from Camberwell, apples from Dulwich and so on.) Seasonality was an accepted determinant of availability. Refrigeration and, earlier, canning/salting (e.g., salmon from Canada, and beef from Argentina) meant that foodstuffs could be transported over distance and urban farm spaces could be infilled. Structurally, the food retail system first depended on peripatetic, then fixed, market stalls where farmers brought produce for sale (now being re-established in caricatural weekend farmers' markets). As the economy grew, the small shop came to dominate the system. Multiple ownership of many small shops under the same fascia - typified by Sainsburys (still one of the leading British grocery retailers) was the next trend. These retailers switched format 
into the supermarket in the post-war period and, from the 1970s, began opening large, automobilebased superstores. Note that the market share of the leading chains in Britain, even as recently as 1980 , was not dominant. For example, in 1982, Tesco had about $9 \%$ of the market share. By 2008 , the market share of Tesco had reached nearly $27 \%$. The losers in the consolidation process were not just independent neighbourhood shops but the 60 or so (smaller) supermarket chains driven from the market or taken over by default. In 2011, the big 4 supermarket chains (viz., Tesco, Sainsburys, ASDA and Morrison) controlled more than $65 \%$ of the British grocery market. Such business entities continue to expand relentlessly: backed by their already enormous financial resources, large portfolios 'land-banked' sites in town centres and peripheries, and the absence of any effective legal restraints. Expansion was routinely undertaken by organic growth and/or by sustained competitive pressure on traditional 'Mom \& Pop' neighbourhood grocers. The net outcome is continued strengthening of corporate dominance in the retail food sector. For decades, the issue of competition and collusion among supermarket multiples in England has stymied the Competition and Markets Authority (known as Competition Commission prior to April 1, 2014 and before that the Monopolies and Mergers Commission). Proving the lack of competition arising from collusion is fraught with considerable difficulties. Tepid vigilance of corporate misdeeds by regulatory bodies has often been cited to be a source of the problem. What is clear is that basic food stuffs are often procured from a limited number of producers through a limited number of distributors. "True" competition may not exist as daily or weekly variance on offered pricing is often deployed as a means to attract prospective food shoppers to the supermarket multiples. This tactic is identical to that of using "loss leader" to bring the buyers to the stores to purchase additionally other goods.

Corporate dominance is tyrannical because it limits the free choices of the public. This situation is becoming increasingly omnipresent due in part to the irreversible change of the agrarian society into an industrial society in Britain since the start of the Industrial Revolution.

As supermarkets become more powerful and more pervasive, the availability and quality of food consumed by citizens is dictated increasingly by the supermarkets in natural consideration of their own profit-driven needs. An example of insidious corporate control is the routine manipulation of retailers to guide the "preference" of buyers at the retail level to fit the corporate objectives. Previous studies by others have shown that consumer needs and preferences could be, and indeed are being, shaped ubiquitously by corporate self-interest (See for example, Harrison et al. 1997; Klein 1999; Hauge 2007; Hinesley 2012). There is also a prevalent counter-view that, instead, it is consumer preference itself that is driving corporate behaviour (see for example, Eckhardt and Mahi 2004; Gehlhar and Regmi 2005). This proposition, though inevitably popular with corporations themselves, does not bear scrutiny. Instead - just as consumers did not clamour for genetically-modified foods most consumer preferences turn out to be driven by corporations. Consider the recent market entry of the river cobbler or basa (Pangasius bocourti), also known as the Mekong River catfish, into British markets. This fish was virtually unknown to consumers in these markets until recently.

There is considerable incentive for agri-food corporations to promote this lower-cost imported fish. The production cost, especially the labour component, is extremely low in Vietnam. The profit margins for distributors but especially for retailers are increased substantially despite the offered retail price being 30 to $40 \%$ lower than that of traditional fish such as haddock and cod. It can be conceded however that at a later stage, after initial product entry into the market, consumer preference has some influence, albeit minor, on changes in product quality, format and presentation. Even the wellmeaning "Fairtrade" scheme to benefit agricultural producers in developing countries has been exploited cleverly by distributors and retailers to increase their corporate profit (Wong and Hallsworth 2013). Labelling of food, often with exaggerated or distorted claims of products is often made until challenged by the public at large. In a way, this practice reflects the prevailing attitude of corporate pursuit of greater profit by any and all means available. 
How did we arrive at this situation? The control of food supply may be traced back firstly to the founding principles of modern corporations, and secondly, to the enormous power of the mega food retailers acquired during the rapid ascendancy of neo-liberal public attitudes and "business-friendly" government policies during the past few decades.

\section{Mandatory pursuit of profit}

In the early history of Christianity, commerce based on extracting extraordinary profit was roundly condemned as immoral and generally un-Christian. St. Augustine (354-430 CE) even declared that "Business is in itself an evil" (Tuchman 1978: 37; VanderVeen and Porter 2001). During the Middles Ages in Britain, we find that any 'social contract' between war lords (later self-titled as "nobles") and peasants merely extended to offering the latter basic food and security, in return for their obedience and servitude (Southern 1953; Bloch 1961; Tuchman 1978; Cantor 1993). Wider concepts of welfare or social justice were not in the lexicon then, under the rigid "Estates" social divisions of clergy, nobility and peasantry. The mercantile class in Britain was not formed from the Third Estate until the late Middle Age (Bisson 1998: Chapters 7 and 8).

\section{Fundamental mandate of the corporation}

In most countries a business corporation is deemed by law to be a "person". Modern corporate behaviour is uniquely un-human because of its existence is based entirely on money which has no "feeling". With startling honesty, Friedman (1962) enunciated six decades ago that any professed justification for social or environmental responsibility by any corporation was just nonsensical deception. The legal reality is that the only social responsibility of a modern corporation is to increase its profit (Friedman 1970). Bakan (2004) has argued that the profit-centric behaviour of a corporation fits well the profile of a psychopath as defined in the Diagnostic and Statistical Manual of Mental Disorders $^{3}$ of the American Psychiatric Association. Indeed one of the defining traits of a psychopath is action taken regardless of all externalities (Hare and Neumann 2008). Increased corporate power and (political) influence afford higher efficiency and effectiveness in the pursuit of profit. It follows that the behaviours of corporate businesses could

not be expected to be "humane". Wong and Hallsworth (2013) have provided a supporting discussion of the psychopathy of profit seeking of modern corporations.

In accord with Friedman, creation of jobs is not, and could never be, a mandate of any corporation. It follows that obsession with short-term profit goals by corporate executives to afford "instant gratification" to shareholders should be considered to be normal practice. There is no moral basis for corporate executives to undertake a different course of action. Perhaps it is naïve to believe that there is morality in the business of profit making. Note that the pursuit of short-term profits could even include self-dismemberment (e.g., divestment) of the corporation if it achieves the goal of maximizing immediate economic returns to the shareholders (see, for example, Hallsworth 1996: 28).

Some see the psychopathy of corporations (Bakan 2004) as self-contained in that the behaviour of people running the companies is essentially segregated from the behaviour of the whole corporation. Babiak et al. (2010) have however observed recently that corporate professionals also possess, or are encouraged to gain, many of the same psychopathic traits of the corporation employing them. This finding was perhaps not surprising as corporations always require people with certain predisposed psychopathic tendencies for profit maximization.

\footnotetext{
${ }^{2}$ Generally known in jurisprudence as persona ficta, of which it is accorded with a legal name and certain rights such as privileges and liabilities, similar to those of a natural person (syn. physical person). This legal concept is widely recognized in both common-law and civil-law countries. See, for example, Kornhauser and MacLeod (2010) and Fritsch (2011) for additional analyses of contemporary corporate personhood.

${ }^{3}$ Commonly abbreviated as DSM. The last major revision was the $4^{\text {th }}$ Edition published in 1994 . DSM-IV codes are widely used by mental health professionals to describe, among other things, features of a given mental disorder.
} 
Despite many attempts to justify the existence of corporate social responsibility over the years (see for example, Smith 2003; Fontaine et al. 2006; Broomhill 2007; Chen 2007), the fundamental tenet of corporate behaviour remains unchanged. In our analysis, corporations might well undertake environmental or social justice activities, but if and only if such activities also increased the profitability of the corporation, particularly in the shortest possible time frame. As ever, Shakespeare has already explained this well. Hamlet ${ }^{4}$ chances upon the King but the latter appears to be at prayer and therefore Hamlet declines to enact revenge. The King soon reveals, however, that his prayers were not sincere: "Words without thoughts never to heaven go"

Fiduciary requirements allow no variance of the short-term pressure for profits. In the current manifestation of free-market liberal economics, there is no room for, say, the Protestant work ethic of yesteryear which implies that people can derive non-monetary satisfaction simply from being gainfully employed (see also Chang 2010: 43). However, in view of the fluidity and relativity of ethics discussed earlier, any demand of ethical behaviour of corporations is weak, at best.

Many do indeed consider that the operation of a modern-day corporation should and could only follow Freidman's doctrine, by the use of all means available (Carr 1968). According to free-market proponents, there should be few, if any, laws to governing the pursuit of maximum profit by private enterprises (Fieser 1996). Paradoxically, of course, private enterprises often promote restrictive laws so long as they facilitate profit making, including protection from unfavourable future changes in government social-economic policies. Their influence is extensive: as Casey (2007: 87) put it when looking at the agri-food sector "...the growing ascendancy of the private sector in the agri-food sphere....power and dominance...manifest in (their) ability to construct ...food safety legislation which would appear to have leap-frogged public food safety standards in ...importance...relegating public food safety regulation to the second tier". The ways in which this has happened in Britain, with powerful retailers interacting with Government is covered, for example, by Harrison et al. (1997) and Pal et al. (2001). Indeed, rent seeking such as political lobbying, bribery of government officials, etc. is considered to be a legitimate corporate activity in the free-market economy (Krueger 1974).

Even though a corporation is deemed to be a legal person, no corporation has in toto ever been jailed for any legal misdeeds ${ }^{5}$. Relatively minuscule fines which have been imposed after convictions for corporate crimes against the public, e.g., deceptive pricing practices, deceitful mislabelling of food content, intentional exaggerated nutritional claims, etc. These penalties are often treated in corporate financial records merely as a cost of doing business. In essence, contemporary financial penalties are ineffective in curbing corporate crimes. Indeed some corporate executives are even rewarded personally for financial achievements regardless of any corporate misdeeds. We may safely assume that there are numerous cases which are yet to be revealed. Interestingly nearly all publicly-exposed corporate criminal activities are blamed on the unauthorized action of rogue junior-level employees.

\section{Evolution of corporate power}

Many have canonised Adam Smith as the founder of corporate self-interest, by generally ignoring his Theory of Moral Sentiments and instead reading [usually selectively] from his Wealth of Nations. Smith always suspected that businessmen would collude to raise prices if they could and his plea was actually for family-owned businesses to pursue their singular route to profits. Interestingly Smith had preached the importance of morality for all market participants, without which the free-market system would fail. Smith's "morality" was rooted in the teachings of Christian Protestantism of the day (See, for example, Dawson 1972: 17-18). Curiously Smith also believed that the ever-present danger of shipwreck would deter any sensible country from becoming over-reliant on risky overseas trading.

\footnotetext{
${ }^{4}$ At the end of Act 3, Scene 3 of "Hamlet, Prince of Denmark", a play written by William Shakespeare in about 1600.

${ }^{5}$ Unlike a natural person, a persona ficta could be "jailed" only by suspension of corporate registration or "exterminated" solely by de-registration of incorporation.
} 
The devastating impact of "new" principles of free-market liberalism became evident almost immediately on British society. Well-known examples include the miserable conditions suffered by workers in England during the Industrial Revolution (Engels 1845). In England during the Industrial Revolution, profit was paramount as any externalities pertaining to the nutritional and environmental health of workers were considered to be inconsequential. Industrial workers were considered to be expendable. As noted above, in Ireland millions of people were eliminated through premature deaths by starvation, and permanent emigration of starving survivors to North America and Australia. The Whitehall policy of the time had been to require the starving Irish people to pay for readily available (imported) food with money that they regrettably did not have - essentially in strict adherence to the doctrines of free-market political economy......(Christian) charity breeds slothfulness in the new Age of Enlightenment.

Though the drive to greater profitability at all costs is relentless (Schroeder 2003; Harris 2012) such attitudes have long been criticised. For example, Beaumont (1994: 8) has commented that cutting costs to achieve greater profitability often imposes significant injustices on others such as producers as well as consumers.

Rewarding bigness and power is, of course, inherent in the contemporary free-market liberal economic model. Their corporate leaders are routinely admired and lionized (McAleer 2012), but the negativities of their ruthlessness in the psychopathic pursuit of profit are rarely stressed.

The relentless march of free-market liberalism continued in the following century. Inequality in society became entrenched and expanded as Britain changed from an agrarian society to an industrial society. In the decade after WWII, there was a notable interruption in the trend towards increasing economic inequality (see Wilkinson and Pickett 2010). The patriotism fanned by the Second World War appeared to have caused a notable reduction in trends toward inequality. Example slogans such as 'homes for heroes' indicated that collective national sacrifice led to a degree of collective national reward. The creation of the welfare state by the Atlee Government (1945-1951) attests to this. Certainly businesses, too, seemed happy then to comply with the idea that full employment was a national goal to be collectively desired. However, trends towards equality began to reverse following the oil shock of the 1970s, the rise of inflation and other wider geo-political trends such as the reinvigorated mission for 'free-market capitalism' to destroy 'evil communism'.

The most recent manifestation of free-market liberalism is the intertwining of corporate and state interest beginning in the 1980s. This sits in direct contradiction to the expectations of the Hayek (1944) ideology of market libertarianism as a vehicle for the destruction of the tyranny of State control. It may not be just Communist states that were undone by market libertarianism as claimed by many neoliberal ideologues. It may be noted that Hayek's work was the foundation of liberal freemarket policies undertaken by the Thatcher government in Britain in the 1980s - leading to wanton privatization and corporatization of State assets and services, and elimination of many legal restraints on corporate practices. The period of the Thatcher regime (1979-1990) witnessed in the rapid expansion of omnipotent corporations to become the "new gods of civilization". This intertwining of business corporations and the State is reminiscent of the beginning of the intertwining of the Christian church and State in about 4th Century CE. In the end, the Church was subsumed and effectively became an instrument to legitimize many of the actions of secular authorities, i.e., the State (Guroian, 1994: 1-2). Subsequently the role of Church has all but fallen into irrelevancy. In the present case, the State has become increasingly an instrument of the power of corporations, whilst the independent free will of the people becomes subordinated to the pursuit of profit.

Since the late 1950s, corporations became steadily larger and gained increasing political influence. In particular, during the period of the Reagan Presidency (1981-1989) in the USA, corporate dominance rebound to its former levels with considerable fervour (Lynn 2012). It was not long after the start of Reagan's presidency before a precipitous fall-off in prosecutions under the Robinson-Patman Act began (Hallsworth 1990: 555). The existing "fair trading" bases of US competition policy were 
abruptly overthrown. This American period of aggressive "greed-is-good" capitalism coincided interestingly with that of the Thatcher regime in Britain. The interest of corporations has thus become increasingly indistinguishable from that of the State. Braudel (1977: 64) has observed appropriately that "..."Capitalism only triumphs when it becomes identified with the state: when it is the state" (our emphasis). Furthermore, many modern-day governments have assumed many of the psychopathic traits of modern transnational business corporations. For example, in defiance of democratic principles, investment deals are currently being signed that are written in ways that prevent future, more socially-concerned, governments from overturning them (see, for example, Gagné 2012). For example, the current corporate attempts to retain ISDS ${ }^{6}$ clauses in the proposed US-EU TTIP ${ }^{7}$ trade agreement clearly show the possibility of ominous emergence of a new corporate-ruled totalitarianism. Klein (2007) has decried that the current oligopolistic power of modern corporations is leading the people into a new serfdom.

Because of increasingly large amounts of money being involved, the symbiosis of government and businesses continues in a circular fashion. In essence, the power and influence of big corporations in society at large increases as governments become ever more complicit in the practices of big businesses. The food sector is, we argue, closely involved. Busch and Bain (2004) for example, stress that to look at nation-states alone is inadequate because of the growing influence of the private sector and private institutions that are also shaping the global agri-food system. In respect of the British food system, the work of Marsden et al. (2012) is closely associated with analysis of State-Retailer relationships.

As corporations become larger, their influence on consumers and public policies increases substantially (Burt and Sparks 2003; Sparks 2008; Anon. 2012). In respect of food retail, a report for Consumers International (Nicholson and Young 2012) outlined the kinds of abusive practises in respect of suppliers that big retail multiples would indulge in if they were allowed to by State regulators (see also Sables 2014). In light of our observations, it should be no surprise that State regulators mostly do permit such abuses - which affects the consumers ultimately. Some of the abuses - available to large retailers but not small - noted by Nicholson and Young (2012: 26) are:

\section{Listing fees/ threat of de-listing, \\ Demanding unforeseen discounts/ retrospective payments; \\ Return of unsold goods to the supplier: \\ Late payments; \\ Promotion of retailer own brands or copycatting packaging on leading brands.}

Additionally, many critics have noted that big British food retailers can reduce their VAT payments by shipping via Jersey - one of the many legitimate tax havens controlled and condoned by successive governments. Indeed for many years, Dole, Chiquita and Fresh Del Monte in the food sector have legally been avoiding some British taxes by trading through subsidiary companies in the Channel Islands among other tax havens (Griffiths and Lawrence 2007). Again, this situation should not be unexpected when the only fiduciary duty of a corporation is to maximize profit for its shareholders.

Lynn (2012) sees such concentrated corporate power as dangerous and anti-democratic. The accusation of being anti-democratic is made whenever it appears that the civic agenda of elected public officials is effectively being controlled by corporate interests. In some cases this can include the financing of political candidates or paying undisclosed financial rewards to retired "businessfriendly" politicians and their families.

\footnotetext{
${ }^{6}$ Investor-state dispute settlement, a legal instrument allowing an investor to sue a foreign government if laws and regulations enacted in the future diminish the profit-earning ability of the investor.

${ }^{7}$ Transatlantic Trade and Investment Partnership, the free-trade agreement being negotiated in secret between the United States and the European Union.
} 
The more that mergers take place the further we move from competitive markets with many products, many suppliers and many rivals in every sector (note that the efficiency argument behind mergers generally fails to stand up). Unfortunately, this problem is fundamentally circular as "monopoly is the end product of competition" (Harvey 2003: 96). In other words, heightened market competition also drives companies out of business (by bankruptcy, for example) to result in fewer business entities. This was amply demonstrated by the sub-prime meltdown which resulted in fewer but even more powerful banks. What is also clear is that this process goes on in a series of waves - as well chronicled 30 years ago by Dicken and Lloyd (1981: 66-69).

There are numerous means available to circumvent prohibitions on collusion (ironically, rules also prohibit co-operation between businesses even if that would give all suppliers a better deal). For example, the concept of horizontal cooperation between corporations (EC 2011) is neither innocent nor benign, because new EC regulation effectively legalizes the raising of entry barriers against new market participants with fewer financial resources, and the setting of "industry standards" by corporations who already have considerable financial resources and substantial market dominance. This practice may also be termed ubiquitously as 'rent seeking'.

In many British businesses, the use of taxpayer funded income-support mechanisms to boost low paid workers, many, as noted, in retail, can be seen as a form of permanent corporate bail-out. Big 4 food retailers benefit, too, when they are allowed to keep most of the massive rise in land values that follows when they are permitted to open a large new store. In contrast to their lowly-paid, taxpayersubsidised workers, corporate executives are routinely paid enormous financial compensation. In banking this can even come from the very same public funds allocated to bail-out their prior misdeeds. Of corporate remuneration, John Kenneth Galbraith (1908-2006), a noted CanadianAmerican economist, once remarked that it resembled 'a warm personal gesture by the individual (viz., Chief Executive Officer) to himself (or herself)'. Interestingly, the situation is even more perverse since large corporations are not participating in funding the financial bail-outs: many (multinational) corporations themselves pay little or no corporate income tax. The legal tax evasion practices of large corporations have been raised again recently (Rushe 2012; Rawlinson 2012; Wright 2012) as more money (re-allocated from the concomitant reduction of essential public services provided by the government) is extracted from ordinary citizens to pay for the financial adventures and misadventures of modern corporations.

\section{Outlook}

Predictions are difficult: few observers at the key turning point of the late 1970s would have anticipated virtual market dominance by four big British food retailers. The laissez-faire-driven reduction of choice and local distinctiveness that results from easy mergers and takeovers shows little sign of reversal. Competition Authorities have ignored calls for de-mergers and so market concentration goes on - most likely towards a big 2 given that 60 British supermarket store fascias have disappeared since WWII. That said, retailers are not immune to wider social and economic trends. The hypermarket/supercentre sector is predictably losing ground as rising fuel costs and the unaffordability of the overloaded shopping cart forces poorer shoppers to shorter, nearer, but smallervolume shopping baskets. The poor are defecting to low-cost discounters such as Aldi and Lidl to charity shops, food banks and 'pound shops'. Consequently the big four see minor erosions in market share. However, the defection to smaller 'convenience' style shopping is not necessarily a godsend for small independent specialists such as butchers. Shoppers still tend to use grocery generalists who sell pre-processed foods. In order to undercut specialists such as butchers, all of the Big 4 offer in-store freshly cut meat, for example. In order to control the emerging convenience-store sector, Tesco and others have been establishing smaller grocery stores, e.g., Tesco Metro, in many urban locations.

Where the low-mortgaged wealthy middle classes live in numbers (typically picturesque but expensive market towns in the affluent south), there has been some success in rejecting the Big 4 food retailers. For example, upscale Waitrose supermarkets seem to be thriving. Moreover, the shorter, 
local, supply chains of specialists such as upscale butchers in such towns appeals largely to those concerned more about provenance than price. Optimism does not, however, extend far. The Big 4 still dominate an increasingly-privatised food supply chain. It is difficult for small-scale producers to move food efficiently in compliance with the terms and conditions set by the Big 4 demand such as holding large inventory buffer, "just-in-time delivery", and assuming full financial burden for any corporate-ordered retail discounts.

For many decades, Britain has been a destination of choice for migrants. For example, in Southall (London), Indian grocers are predominant, with commensurately reduced presence of supermarket multiples. Migrants from the Indian subcontinent prefer grocery stores specialising in foods catering to Indian cuisine. It would be impracticable and not profitable for the Big 4 to engage with this segment of the market directly. It may however be added that in recent years certain supermarkets are carrying wider selection of Indian-specific foods - testimony to the widening popularity of Indian food. It may even be that subsequent generations of these immigrants are relying increasingly on established retail chains for staples and other "main stream" foods, as they move away from the traditional areas of in-migration. More recently large scale immigration from Poland has triggered the establishment of numerous independent groceries selling mainly Polish homeland foods. Hammersmith (London) is an example location where there is a high concentration of Polish national residents. Interestingly both Tesco and Sainsburys supermarkets continue to be present prominently in and around the Hammersmith tube (underground rail) station area.

\section{Limited scope of remediation}

Elster (2007: 95-96) observed that "peasant rebellions in pre-industrial England were invariably unsuccessful .....and their leaders punished harshly... (yet) the rebellions had a long-term success in making the propertied classes behave more moderately than they would have done otherwise". Although the discontent leading to the 1381 English peasants' revolt was much more severe (Hilton 1973), there has been no emergence of contemporary widespread social unrest despite some public indignation over numerous corporate malfeasances and other excesses in the food sector. Not everyone, however, has seen the British population in general as a likely source of widespread protest on such matters. Possibly the most respected, almost revered, of postwar BBC political commentators was the late John Cole. On December $6^{\text {th }}$ in the Orwellian year of 1984 , he made a radio broadcast that was unforgettable by those who heard it. Whilst criticising Government secrecy, Cole also severely criticised the public themselves for their lack of concern. Too many were, he stated, like Orwell's proles, who comprised $85 \%$ of the population, 'quarrelling about the lottery.....watching endless pap on television, unable to string two thoughts together'. As he put it '...governments have grown more skilled in pulling the wool over the public's half-open eyes". Though protests did break out in Bristol in April, 2011, when Tesco attempted to open a store in some secrecy, it may well be that, as Cole feared, the present-day bourgeoisie have been largely co-opted and pacified. The total self-destruction of capitalism in the manner predicted by Karl Marx (Berlin 1963: Chapter 10) was perhaps wishful thinking. If a hegemonic global state is one day imposed, it will certainly not be a communist one on the Soviet model. Whatever the wider social and environmental costs, middleincome Britain still happily drives to shop in big-box supermarkets, often claiming that neighbourhood grocers are uncompetitive. In fact, popular television programmes in Britain sometimes feature 'shopping basket' inquiries that reveal prices to be higher in supermarkets than on traditional street markets. In reality, the principal reason for shopping in supermarkets is the convenience of being able to drive to free parking and buy everything in one store. This is abetted by the wide variety of goods offered, advertising that emphasises low prices, etc. Unlike many struggling neighbourhood stores, only giant food retailers can afford the features that result from the aggressive deployment of their power to procure lowest-price goods from around the World. The driving force for the giant food retailers is of course self-interest for increased profitability. The plight of local producers and local shops could not, and would not, be a consideration in their corporate decisions. 
Appeal to Christian ethics, particularly in an increasingly multicultural society, is not practicable as the people have no inherent moral rights over the purchase of goods and services from large corporations. Interestingly, EU has a Bill of Rights of Airline Passengers since 2005. But there is no Bill of Rights for public buyers of foodstuffs. Such a Bill is acutely needed in the complete absence of underlying ethics in the psychopathic pursuit of corporate profit, to the detriment of the people at large. Seven decades ago, T.S. Eliot (1940: 10) lamented the ascendancy of secular liberalism to supplant benevolent Christian principles in English society. Interestingly Eliot had also predicted the ultimate self-destruction of secular liberalism and the subsequent re-formation of an ethical Christian society. But to date, there is little or no evidence that such an event has occurred or might occur. The obstacles to the revival of early Christian principles and ethics in the public sphere of contemporary liberal society are formidable (Guroian, 1994: Chapter 1). Return to the classical, truly competitive, capitalistic market society sought by campaigners such by Lynn (2012) and others would appear to be unattainable. Regrettably there will be no Second Coming.

Rectification of power imbalances between the people and the corporate controllers of food supply requires governmental or supra-governmental actions. Unfortunately, it is those governmental and supragovernmental agencies that force open markets by use of Structural Adjustment Programs (Chang 2010: 118) and other liberal free-market policies. Indeed, in 2011, the Court of Justice of the European Union ruled that Catalonia (Spain) was not allowed to ban hypermarkets in order to defend its regional food culture $^{8}$. The common weal has become an antiquated rhetoric when the pursuit of instant personal gratification and the glorification of personal wealth are paramount. Thanks to such policies, the psychopathic pursuit of corporate profit has become an entrenched fixture of modern capitalism. There may be no clinical cure for this psychiatric disorder. The contemporary state of society in Britain does not afford any realistic opportunities for significant changes.

\section{Concluding remarks}

Tyranny may be characterized as the diminution of free choice of citizens at large: offering an ironic twist to the Thatcher-Reagan ideology of destroying the tyranny of the State to give the people more free choices. Its replacement is the tyranny of the Corporate State, wherein citizens' exercise of free choice is once again limited. The essentials of life such as food must increasingly be purchased from a few suppliers who have decided a priori what precise mix of products and/or services to provide in order to achieve profit maximization. There is no practicable alternative. It is essentially impossible for citizens in an urban setting to grow their own foods for sustenance as a means to regain declined freedom of choice. The prevailing cash-based economy requires wage-earning employment.

The architecture of the modern corporation embodies mandatory practices which are fundamentally short-termist and opposed to the long-term social and economic well-being of citizens at large. By legal statutes, corporations are driven to pursue greater profit relentlessly and by whatever means available. It is to be expected that any social justice initiatives which do not increase corporate profit would be dismissed and undermined.

But what can now be done to restore some counter-balance to the over-bearing oligopolistic power of huge food-supply corporations? Unfortunately there are few means available to rectify this unsatisfactory situation within the framework of the same free-market economy that created the problem. Any appeal for corporations to adhere to conventional (Christian) ethics is unlikely to succeed. A major paradigm shift away from the capitalistic pursuit of short-term profits is surely needed. But the task to moderate the deeply-entrenched psychopathic pursuit of profit as the foundation of the modern corporation would be formidable. Containment by direct actions of consumers including boycotts, and vocal appeals to elected representatives to enact restraints on the current unfettered capitalism could, at best, only partially remedy the situation.

\footnotetext{
${ }^{8}$ Judgment in Case C-400/08, Commission v Spain; http://curia.europa.eu/jcms/upload/docs/application/pdf/201103/cp110023en.pdf.
} 


\section{References}

Anon. 2012. 'Paying a price for superstores', The Irish Times-Ireland, May 7, available at http://www.irishtimes.com/newspaper/opinion/2012/0507/122431568661.html accessed last 7 May 2012.

Atkins,_P .J. 2003. "Is it urban?". In: M. Hietala and T. Vahtikari, eds., The Landscape of Food, Finnish Literature Society, Helsinki.

Babiak, P., Neumann, C.S. and Hare, R.D. 2010. 'Corporate psychopathy: Talking the Walk', Special Issue: International Perspectives on Psychopathy, An Update, Behavioral Sciences and the Law, 28, 174-193.

Bakan, J. 2004. The Corporation: the pathological pursuit of profit and power. Viking Canada, Toronto.

Beaumont, C. E. 1994. How Superstore sprawl can harm communities: And what citizens can do about it. Washington: National Trust for Historic Preservation.

Berlin, I. 1963. Karl Marx, Oxford University Press, Oxford.

Bisson, L.M. 1998. Chaucer and the Late Medieval World, St. Martin's Press, New York.

Bloch, M. 1961. Feudal Society. Volume 1 - The growth of ties of dependence. Translated by L.A. Manyon, The University of Chicago Press, Chicago.

Braudel, F. 1977. Afterthoughts on Material Civilization and Capitalism. The Johns Hopkins Symposia in Comparative History. Translated by: P. Ranum. The Johns Hopkins University Press, Baltimore.

Broomhill, R. 2007. Corporate social responsibility: Key issues and debates, Dunstan Paper No.1/2007, The Don Dunstan Foundation, Flinders University, Adelaide.

Burt, S. and Sparks. L. 2003. 'Power and competition in the UK retail grocery market', British Journal of Management, 14, 237-254

Busch, L. and Bain, C. 2004. 'New! Improved? The Transformation of the Global Agrifood System', Rural Sociology, 69, 321-340.

Cantor, N.F. 1993. The Civilization of the Middle Ages, HarperCollins, New York. pp. 195-204.

Carr, A.Z. 1968. 'Is business bluffing ethical?' Harvard Business Review, 46:1, 143-153.

Casey, D. 2007. 'Private food safety and quality standards and the WTO', UCD Law Review, 7, 65-89

Cavalier, R.J., Gouinlock, J., and Sterba, J.P., eds. 1989. Ethics in the History of Western Philosophy, Palgrave Macmillan, London.

Chang, H.-J. 2010. 23 things they don't tell you about capitalism, Allen Lane, London.

Chen, M.E. 2007. National Oil Companies and Corporate Citizenship: a survey of transnational policy and practice, The James A. Baker III Institute for Public Policy, Rice University, Houston.

Coogan, T.P. 2012. The Famine Plot: England's role in Ireland's greatest tragedy, Palgrave Macmillan, New York.

Dawson, C. 1971. The Gods of Revolution, Sidgwick \& Jackson, London.

Delaney, E. 2012. The Curse of Reason: The great Irish famine, Gill \& Macmillan, Dublin.

Dicken, P. and Lloyd, P. 1981. Modern Western Society, Harper \& Row, London.

Eckhardt, G.M. and Mahi, H. 2004. 'The role of consumer agency in the globalization process in emerging markets', Journal of Macromarketing, 24, 136-146.

Engels, F. 1845. Die Lage der arbeitenden Klasse in England. Translated by F. Kelley Wischnewetzky, Otto Wigand, Leipzig:

Eliot, T.S. 1940. The Idea of a Christian Society, Harcourt, Brace, New York.

Elster, J. 2007. Explaining Social Behaviour, Cambridge University Press, Cambridge.

European Commission - EC 2011. Guidelines on the applicability of Article 101 of the Treaty on the Functioning of the European Union to horizontal co-operation Agreements, Official Journal of the European Union, C 11, January 14.

Fieser, J. 1996. 'Do businesses have moral obligations beyond what the law requires?', Journal of Business Ethics, 15, 457-468.

Fontaine, C., Haarman, A. and Schmid, S. 2006. The stakeholder theory of multinational 
corporations, available at http://www.edalys.fr/documents/Stakeholders\%20theory.pdf accessed last 15 March 2012.

Freeman, C. 2009. A New History of Early Christianity, Yale University Press, New Haven. Friedman, M. 1962. Capitalism and Freedom, The University of Chicago Press, Chicago.

Friedman, M. 1970. 'The Social Responsibility of Business is to Increase its Profits', The New York Times Magazine, September 13.

Frisch, D. 2011. 'Commercial law's complexity', George Mason Law Review, 18, pp. 245-300.

Gagné, G. 2012. 'Canada's and United States' policy on foreign investment in the natural resource sector', Paper presented at the 37th Annual Conference of the British Association of Canadian Studies, Cambridge, UK, April 2-4.

Gehlhar, M. and Regmi, A. 2005. Factors Shaping Global Food Markets. In: A. Regmi and M. Gehlhar, eds. New Directions in Global Food Markets. Agriculture Information Bulletin No. 794, Economic Research Service, United States Department of Agriculture, Beltsville (Maryland).

Guroian, V. 1994. Ethics after Christendom: Towards an Ecclesial Christian Ethics, William B. Eerdmans Publishing Company, Grand Rapids (Michigan).

Griffiths, I. and Lawrence, F. 2007. 'Bananas to UK via the Channel islands? It pays for tax reasons', The Guardian-UK, November 6, available at http://www.guardian.co.uk/business/ 2007/nov/06/12/ accessed last 4 November 2012.

Hallsworth, A. G. 1990. 'The lure of the USA: some further reflections', Environment and Planning A, 22, 551-558.

Hallsworth, A G. 1996. 'Short-termism and economic restructuring in Britain', Economic Geography, 72, 23-37.

Hallsworth, A.G. and Wong, A. 2012. 'Magnitude of CO2 emission in supplying tomatoes to Portsmouth, England', World Transport and Policy, 18 (May 3), 13-24.

Hare, R.D. \& Neumann, C.S. 2008. 'Psychopathy as a clinical and empirical construct', Annual Review of Clinical Psychology, 4, 217-26.

Harris, P. 2012. 'They shout at you and harass you': how workers toil at Walmart's US Suppliers', The Guardian-UK, July 25, available at http://www.guardian.co.uk/business/2012/ jul/25/walmart-supply-chain accessed last 25 July 2012.

Harrison, M., Flynn, A. and Marsden, T. 1997. 'Contested regulatory practice and the implementation of food policy', Transactions, Institute of British Geographers, 22, 473-487.

Harvey, D. 2003. The New Imperialism, Oxford University Press, Oxford.

Hauge, A. 2007. 'Dedicated followers of fashion: An economic geographic analysis of the Swedish fashion industry', Geografiska regionstudier, No.76, Uppsala University, Uppsala.

Hayek, F.A. 1944. The Road to Serfdom, Routledge, London.

Hilton, R. 1973. Bond Men Made Free: Medieval Peasant Movements and the English Rising of 1381, Viking, New York.

Hinesley, M.D. 2012. 'An alternative segmentation approach anticipating consumer preferences based on early cultural experiences', Doctoral dissertation, Grenoble Ecole de Management, Grenoble, France.

Kelly, J. 2012. The Graves are Walking: The Great Famine and the saga of the Irish people, Henry Holt and Co., New York.

Kinealy, C. 1997. A Death-dealing Famine: The great hunger in Ireland, Pluto Press, Chicago.

Klein, N. 1999. No Logo, Knopf Canada, Toronto.

Klein, N. 2007. The Shock Doctrine: The rise of disaster capitalism, Knopf Canada, Toronto.

Kornhauser, L.A. and MacLeod, W.B. 2010. Contracts between legal persons, Working Paper 16049, National Bureau of Economic Research, Cambridge (MA).

Krueger, A. O. 1974. 'The political economy of the rent-seeking society', American Economic Review, 64, 291-303.

Locke, J. 1689. Two Treatises of Government, 1823 Edition, J. Gumming, Dublin.

Lymbery, P. and Oakeshott, I. 2014. Farmageddon: The True Cost of Cheap Meat, Bloomsbury Press, London.

Lynn, B.C. 2012. 'Killing the competition: How the new monopolies are destroying open 
markets', Harpers's Magazine, February. pp. 28-34.

Marsden, T., Lee, R., Flynn, A. and Thankappan, S. 2012) The New Regulation and Governance of Food, Routledge, London.

McAleer, M. 2012. 'Key entrepreneurial traits of passion and energy can be acquired by Anyone', The Irish Times - Ireland, November 5, available at http://www.irishtimes.com/ newspaper/finance/2012/1105/1224326138095 pf.html accessed last 5 November 2012.

Nicholson, C. and Young, B. 2012. The relationship between supermarkets and suppliers: What are the implications for consumers?, Consumers International, London.

Ó Murchadha, C. 2011. The Great Famine: Ireland's agony 1845-1852, Continuum International Publishing Group, London.

Pal, J., Bennison, D., Clarke, I. and Byrom. J. 2001. 'Power, policy, networks and planning: the involvement of the major grocery retailers in the formulation of Planning Policy Guidance, Note 6, since 1988', International Review of Retail, Distribution and Consumer Research, 11, 225-246.

Rawlinson, K. 2012. 'Big profits, small bills: How multinationals avoid tax', The IndependentUK, November 5, available at http://www.independent.co.uk/news/business/analysis-andfeatures/big-profits-small-bills-how-multinationals-avoid-tax-8282785.html accessed last 6 November 2012.

Rushe, D. 2012. 'Starbucks dismisses tax avoidance claims', The Guardian - UK, November 1, Available at http://www.guardian.co.uk/business/2012/nov/01/starbucks-dismisses-taxavoidance-claims accessed last 4 November 2012.

Sables, D. 2014. 'How retailers extract money from suppliers', The Grocer (UK), October 4 issue, pp. 15-16.

Schroeder, C. 2003. 'The tyranny of profit: Concentration of wealth, corporate globalization, and the failed US health care system', Advances in Nursing Science, 26, 173-184.

Smith, N.C. 2003. Corporate social responsibility: Not whether, but how?, Centre for Marketing Working Paper No. 03-701, London Business School, London.

Southern, R.W. 1953. The Making of Middle Ages, Yale University Press, New Haven.

Sparks, L. 2008. 'Commentary: When Tony met Bobby', Environment and Planning A, 40, 2793 $-2799$

Tuchman, B.W. 1978. A Distant Mirror. The calamitous 14th Century, Ballantyne Books, New York.

VanderVeen, S. and Porter, B.E. 2001. 'St. Augustine: A role model for Christian business faculty', Paper presented at the 17th Annual Christian Business Faculty Association Meeting, Bourbonnais (IL), USA, September 14, available at http://www.cbfa.org/ html/2001_conference.html accessed last 16 November 2012.

Wilkinson, R. and Pickett, K. 2010. The Spirit Level: Why equality is better for Everyone, Penguin, London.

Wong, A. 2015. 'Caribbean Island Tourism: Pathway to continued colonial servitude', Études Caribéennes, in press.

Wong, A. and Hallsworth, A. 2013. 'Corporate subversion of social-justice initiatives on food and agriculture', Journal of Administration and Governance, 8: 1, 1-10.

Wong, A. and Navarro, E., 2014. 'Assessment of agricultural options available for saving orange cultivation in Ribera Baixa (Valencia, Spain)', Journal of Sustainable Development, 7, 115133.

Woodham-Smith, C. 1962. The Great Hunger, Harper \& Row, New York.

Wright, O. 2012. 'Taxman admits Government powerless to force multinationals to declare profits', The Independent - UK, November 5, available at http://www.independent.co.uk/ news/uk/politics/taxman-admits-government-powerless-to-force-multinationals-to-declareprofits-8282771.html accessed last 6 November 2012. 